УДК : 338. 48 : [94(477.64) “14/17” : 355] : 392.8

https://doi.org/10.52058/2708-7530-2021-9(15)-317-325

Притула Олександр Леонтійович кандидат педагогічних наук, доцент, доцент кафедри теорії та методики фізичної культури і спорту, Запорізький національний університет, вул. Жуковського, 66, м. Запоріжжя, 69095, тел.: (066) 067-77-20, https://orcid.org/0000-0001-8800-8207

Конох Анатолій Петрович доктор педагогічних наук, професор, завідувач кафедри теорії та методики фізичної культури i спорту, Запорізький національний університет, вул. Жуковського, 66, м. Запоріжжя, 69095, тел.: (067) 752-05-54, https://orcid.org/0000-0003-4283-9317

Конох Олена Свгеніївна кандидат наук з фізичного виховання і спорту, доцент, доцент кафедри туризму та готельно-ресторанної справи, Запорізький національний університет, вул. Жуковського, 66, м. Запоріжжя, 69095, тел.: (066) 067-77-20, https://orcid.org/0000-0002-8970-0817

\title{
КОЗАЦЬКА КУХНЯ, ЯК ЕЛЕМЕНТ НЕМАТЕРІАЛЬНОЇ КУЛЬУРНОЇ СПАДЩИНИ УКРАЇНСЬКОГО НАРОДУ В КОНТЕКСТІ РОЗВИТКУ ТУРИСТИЧНОЇ ГАЛУЗІ ЗАПОРІЗЬКОГО КРАЮ
}

Анотація. Статтю присвячено проблемі інтеграції українських народних традицій харчування в туристичну галузь. Розглянута проблема харчування i шляхи іï вирішення на світовому рівні. Зокрема, висвітлені тези доповіді Генерального секретаря ООН в питанні вирішення проблеми харчування в світі. Запропоновано одним 3 шляхів вирішення цієї проблеми, звернутися до традицій народної кухні. Висвітлене поняття козацької кухні, як елемента нематеріальної культурної спадщини українського народу. В статті визначене поняття нематеріальної культурної спадщини, розглянутий вплив туризму на суспільство, як комунікативний засіб. Зокрема визначене питання козацьких традицій харчування, в контексті бачення козацької кухні в ракурсі здорового харчування та як елемента нематеріальної культурної спадщини українського народу загалом в контексті розвитку туристичної галузі в Україні і зокрема в Запорізькому краї. Запропоновано внести козацьку кухню в реєстр нематеріальної культурної спадщини народів ЮНЕСКО. Розглянута козацька кухня, як елемент народної і козацької медицини, козацького здорового способу життя. Визначено, що традиції козацтва $\epsilon$ актуальними для духовно-культурного життя українців, оскільки саме козацтво, є одним з найважливіших маркерів самоідентифікації української нації, як історично, так і в сучасності. Висвітлений історичний аспект козацької кухні, проаналізований стан технології і організації харчування в 
козацькому середовищі в часи існування Запорозької Січі. Доведено, що важливою умовою фізичного і морального здоров'я козаків була кухня - проста, різноманітна і вельми смачна, січова кухня допомагала козакам зберігати своє здорове тіло в часи існування Запорозької Січі. Проаналізовані основні складові складові козацької кухні. Визначено інтеграційну природу козацької кухні, як синтез кухні українського народу та етносів, які населяють Україну. Виведене нове поняття, козацького гастротуризму, його зв'язку з фестивальний, подієвим та іншими видами туризму. Наведені позитивні приклади успішного функціювання козацького гастротуризму в Україні. Запропоновані шляхи i перспективи розвитку козацького гастротуризму в Україні i, зокрема, в Запорізькому краї. Визначено козацька кухню, як магніт туристичної індустрії України і зокрема Запорізького краю, який може надати великий стимул розвитку туристичної галузі в ракурсі козацького гастротуризму.

Ключові слова: нематеріальна культурна спадщина, українська національна кухня, козацька кухня, козацький гастротуризм, туристична галузь.

Prytula Oleksandr Leontiiovych Candidate of Pedagogical Sciences, Associate Professor of Tourism and Hotel and Restaurant Affairs of Zaporizhia National University Zaporozhye, Zhukovsky St., 66, tel.: (063) 741-79-98, https://orsid.org/0000-0001-8800-8207

Konokh Anatoliy Petrovich Doctor of Pedagogical Sciences, Professor, Head of the Department of Theory and Methods of Physical Culture and Sports, Zaporizhia National University, Zaporozhye, Zhukovsky St., 66, tel.: (067) 752-05-54, https://orsid.org/0000-0003-4283-9317

Konokh Andriy Anatoliyovych Candidate of Pedagogical Sciences, Associate Professor of Tourism and Hotel and Restaurant Affairs of Zaporizhia National University Zaporozhye, Zhukovsky St., 66, tel.: (063) 741-79-98, https://orsid.org/0000-0001-9719-0418

\section{COSSACK CUISINE AS AN ELEMENT OF THE INTANGIBLE CULTURAL HERITAGE OF THE UKRAINIAN PEOPLE IN THE CONTEXT OF THE DEVELOPMENT OF THE TOURISM IN ZAPORIZHZYA}

Abstract. The article is devoted to the problem of integration of Ukrainian folk food traditions into the tourism industry. The global food problem and ways of its solution are considered. In particular, the abstracts of the report of the UN Secretary General on solving the problem of nutrition in the world are highlighted. One of the ways to solve this problem is to turn to the traditions of folk cuisine. The concept of Cossack cuisine as an element of the intangible cultural heritage of the Ukrainian people is covered. The article defines the concept of intangible cultural heritage, 
considers the impact of tourism on society as a means of communication. In particular, the issue of Cossack food traditions is identified in the context of the vision of Cossack cuisine in the perspective of healthy eating and as an element of intangible cultural heritage of the Ukrainian people in general in the context of tourism in Ukraine and in Zaporizhzhia region. It is proposed to include Cossack cuisine in the register of intangible cultural heritage of UNESCO. Cossack cuisine is considered as an element of folk and Cossack medicine, Cossack healthy lifestyle.It is determined that the traditions of the Cossacks are relevant for the spiritual and cultural life of Ukrainians, because the Cossacks are one of the most important markers of self-identification of the Ukrainian nation, both now and in the past. The article analyses the historical aspect of Cossack cuisine and the state of technology and organization of food in the Cossack environment when the Zaporozhian Sich existed. It is stated that an important condition for the physical and moral health of the Cossacks was the cuisine - simple, varied, drinkable and very tasty, Sich cuisine helped the Cossacks to maintain a healthy body. The main components of Cossack cuisine are analyzed. The integration nature of Cossack cuisine is defined as a synthesis of the cuisine of the Ukrainian people and ethnic groups inhabiting Ukraine. A new concept of Cossack gastro-tourism, its connection with festival, event and other types of tourism is derived. Positive examples of successful functioning of Cossack gastro-tourism in Ukraine are given. The ways and prospects of development of Cossack gastro-tourism in Ukraine and, in particular, in the Zaporizhzhia region are offered. Cossack cuisine has been identified as a magnet for the tourism industry of Ukraine and in particular the Zaporizhzhia region, which can boost the development of the tourism industry in the perspective of Cossack gastrotourism.

Keywords: intangible cultural heritage, Ukrainian national cuisine, Cossack cuisine, Cossack gastrotourism, tourism industry.

Постановка проблеми. Проблема харчування, якісного забезпеченням повноцінним харчуванням людства на сьогодні є одним з найважливіших питань світового суспільства. Так при ООН створений Постійний комітет системи Організації Об'єднаних Націй з проблем харчування (далі ПКХООН), який був створений в квітні 1977 року. Робота ПКХООН вибудувана відповідно до таких чотирьох стратегічних цілей, сформульованих в його Стратегічному плані на 2016-2020 роки, а саме забезпечення максимальної узгодженості політики ООН та пропагандистської роботи в галузі харчування; сприяння послідовної і підзвітної реалізації програм в рамках системи $\mathrm{OOH}$; вивчення нових $\mathrm{i}$, які з'являються, аспектів в області харчування; заохочення обміну знаннями в системі ООН і за іï межами [1].

В доповіді Генерального секретаря ООН щодо проблем харчування в світі в 2018 році було визначено, що глобальний характер проблеми неповноцінного харчування вимагає всеосяжного підходу до пошуку рішень, які могли б допомогти просунутися вперед. Успіх Десятиліття харчування буде залежати від 
того, чи вдасться об'єднати зусилля традиційних і нетрадиційних суб'єктів, що займаються питаннями харчування, i знайти точки дотику в роботі різних секторів [1].

У зв'язку з цим, виникає проблема пошуку нових ефективних рішень в проблемі повноцінного харчування людини.

Туризм $\epsilon$ однією 3 важливих чинників міжнародних комунікацій, привабливість туристичних продуктів і ефективність галузі в цілому прямо пов'язані 3 інтеграцією національних традицій в світове співтовариство. Рішенням цієї проблеми може стати вивчення і впровадження в сучасне життя старих перевірених форм i методів харчування, зокрема заснованих на національних традиціях [4]. На нашу думку, рішення проблеми харчування людства може міститися зокрема на відродженні національних традицій харчування, оскільки вони пройшли перевірку часом, зберігши людство і народи в своєму існуванні. В Україні це може бути вивчення, відродження i впровадження традицій української національної кухні, зокрема козацької кухні та її популяризація.

Аналіз останніх досліджень і публікацій. Аналіз останніх досліджень і публікацій в галузі традицій української національної кухні, козацької кухні засвідчує, що проблема висвітлюється достатньо в галузі етнічних досліджень, на рівні публікацій в періодичній пресі, або на рівні історичної літератури. Окремі аспекти козацької кухні висвітлені в роботах Д. Яворницького [9], А. Кащенко [3]. Оскільки автори були сучасниками козацтва в останні роки існування, як офіційного явища, то їх опис козацької кухні можна вважати історичним джерелом. Досить грунтовно розглянута проблема козацької кухні 3 точки зору здорового харчування в працях Є. Товстухи [7], О. Середюка [6], які розглядали козацьку кухню, як елемент козацького здорового способу життя.

Незважаючи на досить велику популярність української національної кухні, зокрема козацьких традицій харчування, дана проблема не розглядалося як елемента нематеріальної культурної спадщини українського народу в контексті розвитку туристичної галузі в Україні і зокрема в Запорізькому краї.

Мета статті - визначити складові елементи української козацької кухні, i спрогнозувати ï розвиток в Україні та використання цього явища в туристичній галузі.

Виклад основного матеріалу. Традиції козацтва $\epsilon$ актуальними для духовно-культурного життя українців, оскільки саме козацтво, $€$ одним 3 найважливіших маркерів самоідентифікації української нації, як історично, так і в сучасності.

Запорозьке козацтво, як явище внесло значний внесок в формування основ як української державності, так і в формування самобутності духовності i культури українського народу.

Козацька кухня - це культура козацького харчування, яка в свою чергу $є$ елементом культури козацтва i українського народу. У статті 2 Конвенції 
ЮНЕСКО про збереження нематеріально культурної спадщини дається наступне визначення нематеріальній культурній спадщині: «Нематеріальна культурна спадщина» означає ті звичаї, форми показу та вираження, знання і навички, а також пов'язані 3 ними інструменти, предмети, артефакти й культурні простори, які визнані спільнотами, групами й у деяких випадках окремим особами як частина їхньої культурної спадщини [1].

Така нематеріальна культурна спадщина, що передається від покоління до покоління, постійно відтворюється співтовариствами і групами залежно від середовища, що їх оточує, їх взаємодії з природою та історією і формує в них почуття самобутності та спадкоємності, сприяючи тим самим повазі культурної різноманітності і творчості людини.

Важлива тільки та нематеріальна культурна спадщина, яка узгоджується 3 існуючими міжнародно-правовими актами з прав людини і вимогами взаємної поваги між співтовариствами, групами та окремими особами, а також стійкого розвитку» [8].

У Конвенції вказані також конкретні прояви нематеріальної культурної спадщини в декількох областях: усні традиції та форми вираження, в тому числі мова як носій нематеріальної культурної спадщини; виконавські мистецтва, у тому числі акторська гра, музика, спів, танці та інше; звичаї, обряди, свята; знання та звичаї, що відносяться до природи і всесвіту; знання та навички, пов'язані з традиційними ремеслами [8].

Козацька кухня є елементом козацької традиції. Секрети кухні передавалися 3 покоління в покоління. Питанню харчування запорозькі козаки приділяли особливе питання. Так в кожному курені Запорозької Січі був окремий штатний курінний кухар, який опікувався повноцінним і здоровим харчуванням своїх товаришів. Питання організації харчування в козацтві мало особливе значення.

Цікавою $\epsilon$ характеристика козаків, надана французьким інженером Бопланом. який довго працював в Україні. Він писав: «На зріст гарні, проворні, сильні. 3 природи мають добре здоров'я. Від хвороби вмирають дуже рідко, хіба від старості» [9]. Козацька приказка говорить: «Запорожці, як діти - дай багато все з'їдять, а дай мало - довольні будуть». Військовий побут не передбачав занадто ревнивої турботи про харчування. Раціон харчування козаків був побудований на природній здоровій калорійній їжі роздільного харчування. Саме такий спосіб травлення давав найменші витрати реактивів організму - гормонів, ферментів, шлунково-кишкового соку та повне засвоєння всіх компонентів. Слабкий розвиток землеробства на Запоріжжі означав високу залежність краю від постачання борошна та круп і вживання меншої кількості овочів у раціоні. Але поширеність рибальського промислу і добра забезпеченість товариства рибою, 3 огляду на велику кількість днів посту (189), посідали значне місце. Риба займала головне місце в харчуванні козаків, а м'ясні страви вважалися святковими. Ця традиція збереглась аж до 60 -х років ХХ ст.

Відомий історик Д. Яворницький в своїх працях детально описує процес 
харчування в козацьких куренях: «Обід готувався в кожному курені особливим кухарем, або поварем, і його помічниками, невеликими хлопцями, в обовязках яких було приносити воду в курінь і тримати в чистоті котли і посуд: «посуд котли, ложки, корита, дуже чисто тримають і чистіше, як себе, а тим більше, як одяг». Їжа готувалася у великих мідних або чавунних котлах, які навішувалися за допомогою залізних гачків на кабиці в сіняхкожного куреня, і варилася три рази в день на все наявне число козаків куреня, за що платилося кухарю по два рублі і по п'яти копійок $з$ кожного козака в рік, тобто 9 рублів і 50 копійок при 150 чоловік середнього числа козаків в кожному курені» [9, С. 243]. В куренях Запорозької Січі посада кухаря була штатною одиницею, яка забезпечувалася чималою заробітньою платнею. Це свідчить про важливість питання здорового харчування в середовищі запорозького козацтва, що в свою чергу об'єктивно мало створити саме козацьку систему здорового і безпечного харчування. Вчений дає опис і назви страв, які готувалися в козацьких куренях на Запорозькій Січі: «До столу, який по-запорозькому називався «сирно» звичайно подавалися саломаха або саломать, тобто ржана мука, густо зварена з водою; тетеря, тобто ржана мука або пшоно, не дуже густо зварене на квасі, щерба та рідко зварена мука на риб'ячій юшці» В козацькому раціоні на Січі їжа була проста і варена на основі ржаної муки, або пшона. Провізія для їжі або доставлялася кожному куреню після розподілу царської хлібної платні, або купувалася на громадські гроші всього куреня, які завжди трималися в курінній скарбниці під керівництвом курінного отамана [9, С. 244]. За даним описом організації харчування в козацькому курені, можна зробити висновок, що процес організації харчування на Запорозькій Січі мав особливе суспільне значення.

Видатний український запорізький дослідник козацьких традицій, мандрівник і письменник В. Супруненко звертає увагу на те, що особливістю козацької кухні і безпосередньо кухні запорізького краю був борщ, який на запорізькій землі традиційно готувався дуже різний: на м'ясному бульйоні та пісний з квасолею чи без, з доданням сала, зі шкварками, смаженою рибою, 3 підсмаженим борошном і обов'язково - з зеленню, на яку так багатий південний український степ. А також із заправкою з попередньо обсмаженої перед доданням у борщ суміші цибулі, моркви і буряка. Особливістю козацької кухні $\epsilon$ комбінування вареного 3 смаженим, що обумовлено кліматичними характеристиками запорізького краю. В умовах високих температур, властивих регіону, обсмажування продуктів $є$ необхідністю для їх максимально тривалого збереження. Тому на запорізькій землі смаження стала такою ж частиною кулінарної культури, як і традиційне для слов'ян приготування за допомогою варіння [2].

На думку О. Середюка, козацька кухня складалася 3 кашоподібних страв 3 різних злаків - саламаха, тетеря, щерба, кулеші. Їх вживали з медом, молоком, рибною юшкою. Значне місце в харчуванні козаків займала риба: лящ, короп, осетер, сом, вугри, лини, піскарі, щука, в’язі. Вживали також ікру різних пород 
риб. М'ясні страви вважали святковими [6].

Дослідники козацької кухні (О. Сердюк [6], В. Супруненко [2]) донесли до нас цілий спектр страв козацької кухні з рецептами: борщ з воловини, телятини або свинини, борщ 3 карасями, юшка $з$ риби, юшка грибна, українські галушки, вареники з сиром, кулеша, пшоняна каша, гетьманська каша, гетьманська печеня, гетьманський куліш, кутя, узвар, вишняк на меду та ін. Всі ці страви несуть в собі оригінальні рецепти, які утворилися протягом існування запорозького козацтва і передавалися в родинах, як спадщина.

Видатний дослідник народної і козацької медицини Є. Товстуха розглядає козацьке харчування не лише, як здорове, але i таке, що має оздоровчий i лікувальний ефект. Вчений стверджує, що «народна ужиткова творчість українців витворила десятки, сотні і тисячі різноманітних страв, напоїв, закусок, також звертає увагу на високу загальну культуру та знання елементів загальної та харчової гігієни. Стіл, піч, груба, мисник, комори, льох, де зберігаються харчові продукти або готова їжа, завжди за народними традиціями, годиться тримати в чистоті. Біля харчових прродуктів зберігають обереги: хрін, цибулю, часник, селеру, редьку, петрушку» [7, С. 185].

Отже, козацька кухня багатогранна, маючи глибокі історичні корені, зберегла свою самобутність і самоідентичність. Це може слугувати приводом для подання цього, явища до внесення в реєстр нематеріальної спадщини народів ЮНЕСКО. В свою чергу реалізація даного проекту дає можливість до більшого інтересу людства до такого явища, як козацька кухня.

При організації туристичного продукту з елементами харчування козацтва $\mathrm{i}$ козацької кухні можна організувати інтерактивні дійства 3 реалістичною реконструкцією приготування козацьких страв в атмосфері діяльності курінного кухаря і його служби.

Козацька кухня може стати магнітом туристичної галузі запорізького краю $\mathrm{i}$ України в цілому. Страви козацької кухні смачні і відносно не дорогі в приготуванні. Це, при певному створенні козацького інтерактивного середовища на туристичних об'єктах, змогло б створити додаткову туристичну привабливість. При цьому могла б утворитися ціла галузь - козацький гастротуризм.

Козацький гастротуризм в свою чергу наситив би видовищно подорожі туристів, придав би місцевий колорит туристичній галузі запорізького краю. Підтвердженням цього є вже багаторічне існування таких туристичних об'єктів 3 козацьким наповненням, в тому числі і з козацькою кухнею, як «Соколиний хутір» на Чернігівщині, «Мамаєва Слобода» в Києві, кінний театр «Запорозькі козаки» на о. Хортиця та інші поодинокі подібні проекти. Успішне багаторічне існування даних проектів на ринку туризму в Україні свідчить про затребуваність даної форми козацького гастротуризму. Причому, успішне існування даного проекту на нашу думку можливо тільки в комплексі використання інтерактивної складової роботи 3 туристичними групами. Козацька кухня має бути оточена 
козацькими виставами, показовими виступами, танцями, співами. Можливі майстер-класи 3 приготування туристами простих блюд козацької кухні, кулінарні конкурси.

Козацький гастротуризм можливо використовувати, поєднуючи його 3 фестивальним та подієвим туризмом. Прикладом поєднання козацького гастротуризму 3 подієвим та фестивальним $є$ Міжнародний фестиваль національних воїнських та традиційних культур «Запорозький Спас» імені Анатолія Срмака, який проводиться в Запоріжжі на о. Хортиця 25 років поспіль. Успіх фестивалю базується в тому числі і на традиційних виставках-продажах козацьких страв. Також козацькі страви в останні роки стали своєрідним символом Запорізького регіону. Опитування глядачів телеканалом «Z» міста Запоріжжя, переважна більшість туристів, назвала козацький куліш традиційною стравою Запоріжжя, символом кулінарної справи міста.

Висновки. Козацька кухня може стати елементом нематеріальної культурної спадщини України, як один з маркерів української самоідентичності. Вона має інтеграційну природу, як синтез кухні українського народу та етносів, які населяють Україну. Козацька кухня має стати магнітом туристичної індустрії запорізького краю, України.

\section{Jimepamypa:}

1. Доповідь Генерального Секретаря ООН з проблем харчування [Електронний ресурс]. - Режим доступу: https://ukrainepravo.com/international_law/public_international_law/dopovidgeneralnogo-sekretarya-oon-z-problem-kharchuvannya/

2. Запорозька О. Запорізька кухня прикрасить стіл і придасться в поході. [Електронний pecypc]. - Режим доступу: https://www.ukrinform.ua/rubric-regions/2360992-zaporizka-kuhnaprikrasit-stil-i-virucit-v-pohodi-ros.html

3. Кащенко А. Оповідання про Славне Військо Запорозьке Низове [Електронний pecypc]. - Режим доступу: http://kaschenko.us.org.ua

4. Непочатенко В.О. Матеріали Всеукраїнської науково-практичної конференції «Стратегічні перспективи туристичної та готельно-ресторанної індустрії в Україні: теорія, практика та інновації розвитку» (м. Умань, 30-31.10.2019р.). Умань: Візаві, 2019. С.126-128.

5. Пастернак А. Козацька медицина. [Електронний ресурс]. - Режим доступу: http://ukrlife.org/main/minerva/cossak_m.htm.

6. Середюк О.М. Енциклопедія козацтва. Лицарі Сонця. - Київ: ФОП Стебеляк, 2019. 488 с.

7. Товстуха Є. С. Українська народна медицина. - Київ: видавництво «Рось», 1994. 342 с.

8. Офіційний сайт конвенції про збереження нематеріальної культурної спадщини. [Електронний ресурс]. - Режим доступу: https://ich.unesco.org/index.php?lg=EN\&pg=home

9. Яворницький Д.І. Історія запорізьких козаків: У 3 т. / Редкол.: П.С. Сохань (відп. ред.) та ін. - Київ: Наук. Думка, 1991. Т.1. 592 с.

\section{References:}

1. Dopovid Heneralnoho Sekretaria OON z problem kharchuvannia [Report of the UN SecretaryGeneral on Nutrition]. Access mode: https://ukrainepravo. com/international_law/public_international_ law/dopovid-generalnogo-sekretarya-oon-z-problem-kharchuvannya [in Ukrainian].

2. Zaporizka O. (2012) Zaporizka kukhnia prykrasyt slil i prydastsia v pokhodi. [Zaporozhye 
cuisine will decorate the table and come in handy on the hike] Access mode: https://www.ukrinform.ua/rubric-regions/2360992-zaporizka-kuhna-prikrasit-stil-i-virucit-v-pohodiros.html [in Ukrainian].

3. Kashchenko A. (2011) Opovidannia pro Slavne Viisko Zaporozke Nyzove [The story of the Glorious Zaporozhian Lowland Army] Access mode: http://kaschenko.us.org.ua [in Ukrainian].

4. Nepochatenko V.O. (2019) Materialy Vseukrainskoi naukovo-praktychnoi konferentsii «Stratehichni perspektyvy turystychnoi ta hotelno-restorannoi industrii v Ukraini: teoriia, praktyka ta innovatsii rozvytku» [Proceedings of the All-Ukrainian scientific-practical conference "Strategic prospects of the tourism and hotel and restaurant industry in Ukraine: theory, practice and innovation of development"] Uman: Visa [in Ukrainian].

5.Pasternak A. (2008) Kozatska medytsyna [Cossack medicine] Access mode: http://ukrlife.org/main/minerva/cossak_m.htm.

6. Serediuk O.M. (2019) Entsyklopediia kozatstva. Lytsari Sontsia [Encyclopedia of the Cossacks. Knights of the Sun]. Kyiv: Private individual Stebelyak [in Ukrainian].

7. Tovstukha Y.S. (1994) Ukrainska narodna medytsyna [Ukrainian folk medicine]. Kyiv: Ros Publishing House [in Ukrainian].

8. Ofitsiinyi sait konventsii pro zberezhennia nematerialnoi kulturnoi spadshchyny. Access mode: https://ich.unesco.org/index.php?lg=EN\&pg=home [in Ukrainian].

9. Iavornytskyi D.I. (1991) Istoriia zaporizkykh kozakiv [History of the Zaporozhian Cossacks]. Kyiv: Nauk. Opinion [in Ukrainian]. 